\title{
Teaching Speaking for Professional Context Using Prezi in the Relation With Students' Creativity
}

\author{
Marisa Fran Lina \\ IAIN Salatiga \\ marisafl@iainsalatiga.ac.id \\ DOI: http://dx.doi.org/10.18326/rgt.v11i2.154-167
}

Submission
Track:
Received:
05/07/2018
Final Revision:
25/11/2018
Available online:
01/11/2018
Corresponding
Marisa Fran Lina
marisafl@iainsalatiga.ac.id

\begin{abstract}
This study is purposed to know whether Prezi is useful to teach Speaking class and the high creative students are more superior speaking skill than low creative students. This study was conducted for second semester students of English Education Departmentat IAIN Salatiga in 2016. In this study, the writer used experimental research method. She examined two classes as the experimental class and control class. There were two groups in each class (high and low creative students). The students' creativity test and speaking test became the research instruments. Both tests were readable with the result of more than $75 \%$. The analysis used was (ANOVA). The results are: (1) Prezi is useful for teaching speaking for professional context; (2) The high creative students are more superior in speaking skill than low creative students. Thus it can be summed that: Prezi is a useful media to teach Speaking for Professional Context, so the learning goal will be accomplished namely make students can make, use, or apply the material creatively therefore English teacher should use it. Prezi is also appropriate for high and low creative students since it has flexible movement which helps students can organize the topic into the meaningful sentences. Then, the students can deliver their idea smoothly through oral performance.
\end{abstract}

Key words: Prezi, Teaching Speaking, and Creative Students 


\section{INTRODUCTION}

One of important skills that should be owned by university students, especially in English Education Department, is speaking. According to Sharif (2012: 2) speaking is the act of delivering information or expressing someone's ideas and senses in oral language. It is definitely crucial while it came into teaching time for the students as teachers in the future. The reason is they have to use this skill to teach their students in order to deliver the material, give instructions and feedback to their students, and do some other teacher's activities in the classroom. Thus, producing speech fluently and confidently will be necessary as an English teacher, since the teacher will be the model for the students.

Based on the experts' descriptions about assessing speaking, the writer determines to use Massachusetts Department of Education Assessment of Basic Skills's scoring rubric (Sujiyana, 2010: 36) since the scoring scale is more suitable to examine individual presentation as one way communication. The total of maximum score got by one student is 20 since the maximum point of every aspect is 4. After that, the student's score is converted into 100 points scale by multiplying it with 5 so that it is easier to calculate. Massachusetts Department of Education Assessment of Basic Skills in also describes about aspects for assessing students' speaking performance, they are (1) Fluency, (2) Vocabulary, (3) Pronunciation, (4) Grammar, and (5) Content. Meanwhile, there is micro and macro skills of speaking as stated by Brown (2003: p. 142-143). The micro skills refer to making the smaller parts of language namely phonemes, morphemes, words, collocations, and phrasal groups. The macro skills mean the speakers focus on the bigger elements: discourse, fluency, function, cohesion, style, nonverbal communication, and strategic options.

From the explanations, the researcher tried to create construct. The construct is explained as follows: speaking is an activity to make speech orally to express thought and communicate them to others. By speaking, people attempt to create words and even smaller chunk of words. Speakers also have larger elements of speaking skill namely fluency and nonverbal communication. To assess someone's speaking skill, it needs some aspects, and they are vocabulary, pronunciation, fluency, content, and grammar. Those aspects also have their own characteristics to assess speaking. In addition, the researcher creates elements and indicators of speaking which are explained as follows: the speakers are denoted having speaking skill if they have obtained skill to perform speaking activity appropriately that includes five speaking elements. They are vocabulary, pronunciation, fluency, content, and grammar. Then, the indicators of speaking ability that indicates the speaker can accomplish speaking skill are in 
REGISTER JOURNAL

Vol. 11, No. 2, Vol. 11, No. 2, 2018, pp.121-138 p-ISSN: $1979-8903$; e-ISSN : 2503-O4OX

Website: http://journalregister.iainsalatiga.ac.id/index.php/register/ http://dx.doi.org/10.18326/rgt.v11i2.154-167

detail: (1) the speaker produces extensive vocabularies, (2) the speaker uses very clear pronunciations, (3) the speaker can speak fluently, (4) the speaker performs superior relevance and coherence of ideas and (5) the speaker is able to produce very few grammatical mistakes.

Still in line with this, technology as the development of human's activities today has also impacted to English teaching specifically in speaking area. Boonkit, 2010 in Pujasari (2014: p.1) states that the sophisticated world media, mass communication, and Internet asks an English excellent skill, especially for oral English. Therefore, it is hoped that a university student who is going to be an English teacher can apply appropriate technologies in teaching speaking. This reason also underlies the importance of conducting a research in speaking especially in the aspect of technology.

\section{The Contribution to Knowledge}

The Syllabus of Tadris Bahasa Inggris (TBI) or English Education Department at IAIN Salatiga under Religous Ministry demands that the standard competency as a second semester of university student in English Department Program in Speaking in Professional Context is that students are hoped to make and apply the material of Speaking in Professional Contexts creatively (TBI: 2016).

Meanwhile, there is a new presentation software namely Prezi. It is a free online visual presentation device launched in 2009 that permits the audience to connect with the content by changing around, zooming in and out on a big canvas that can be filled with text, images, and video (Fransson \& Holmberg 2012 in Brock, 2013: 96).

On the other hand, PowerPoint presentations look standard and linear. White (2012: 16) says that PowerPoint has problem in getting to a specific slide when presentation has begun. Additionally, the PowerPoint presentation is arranged in a linear order, so it limits the presenter to show her content of the presentation at once. It is also because in PowerPoint, that is difficult for the user to simply click the background with mouse to make the presentation zooms out to a big overview, and the presenters cannot zoom into the area they want (Lorang, in White (2012: 12)). These conditions certainly influence the flow of information of the presenter in presenting their ideas.

To prove its usefulness, the researcher compares Prezi with PowerPoint. In PowerPoint, as stated by Sari (2014: 933), the university students ordinarily use PowerPoint. It is one of presentation media; it is based on standard slides. On the other hand, Prezi is considered more attractive since the features are interactive and visually helpful appliances that practice zooming and dimensional relations to show information. It is going to please the university students be successful in delivering a fair idea orally. Manning, et al. (2011 in Sari, 2014: 933) also adds that Prezi is virtually akin to PowerPoint. However, Prezi has the capability to combine various distinct kinds of media. Meanwhile, Ansori (2012: 18) 
states Microsoft Office PowerPoint is a computer program for presentation developed by Microsoft. It is one package of Microsoft Office and run under Microsoft Windows system operation. The plus point of PowerPoint has been stated by Barber (2013:1) that more people are familiar with the PowerPoint format.

Furthermore, the writer found facts in her preliminary research in a speaking class that in delivering explanations to others using English orally, pupils feel difficult. It appeared especially once the students presented their topic in PowerPoint software. They felt unpleasant to show and explore the topic using this software. In a presentation activity, a student looked unconfident. She inclined to read the presentation rather than talk or explain. When the teacher asked her to describe one part of slides, she could not say something, she only ordered the audiences to read the slides by themselves. The student looked troublesome to present in the activity using PowerPoint. Additionally, the audiences inclined to concentrate on the PowerPoint slides rather than toward what the speaker said.

Afterward, creativity is a significant part of speaking and it can influence students' speaking skill. Magno and Ouano (n.d.: 229) defines creativity as the innate ability of the person to produce or create something out of local substances or resources, having the ability to state oneself wants, wide imagination and high tendency to music arts and culture. Harris and McCan (1994: 21) also mention creativity in presentation. It presents initiative, original thought, inventiveness and it shows work tidily and in an ordered manner. Meanwhile, Craft, Jefrey and Leibling (2007 in Alajaili, 2014: 36) explain that creativity is a process of fashioning, shaping, molding, refining and managing the creative idea or activity. It can be summed up that creativity is thinking actively to create something new and attractive in order to solve problems. Therefore, the use of teaching media such as Prezi and PowerPoint will encourage students to indulge their creativity in speaking activities.

The writer proposes that Prezi as the most update product of presentation tool is determined to be more useful than PowerPoint in teaching speaking. Consequently, this study tries to prove which media is appropriate to teach speaking in the campus level. This study also highlights on the use of technology in teaching filed since it should be propagated specifically in teaching speaking. Moreover, it is very important for the students in the campus who will be teachers in their future. Additionally, this study emphasizes on students' creativity which is connected tightly to produce a good product of speaking by the teaching media. The reason is because the implementation of Prezi and PowerPoint as the learning media demands students' creativity to elaborate the speaking material. 
REGISTER JOURNAL

Vol. 11, No. 2, Vol. 11, No. 2, 2018, pp.121-138 p-ISSN: 1979-8903 ; e-ISSN : 2503-040X

Website: http://journalregister.iainsalatiga.ac.id/index.php/register/ http://dx.doi.org/10.18326/rgt.v11i2.154-167

\section{Purpose of the Study}

The purposes of the research are to know whether: (1) Prezi is more useful than PowerPoint to teach Speaking for professional context; (2) The high creative students are more superior than low creative students in speaking skill.

\section{Review of Related Studies}

There are some related researches about Prezi, among of them are:

1. Prezi: An Online and Offline Zooming Presentation Tool in Oral English for Academic Speaking Pupils. The writer is Sari (2014) who concludes that the implentation of Prezi in oral English specifically for Academic speaking students is hoped to create a good presentation. By using Prezi, students can use an attractive media to present message clearly. Prezi owns more superior visual designs which have an important role for an audience's attraction and attention span. Prezi in oral presentation is going to increase the students' speaking abilities.

2. A Story of Two Cultures: Cross Cultural Comparison on Learning the Prezi Presentation Software Device in the US and Norway. This research was conducted by Brock and Brodahl (2013) and the result shows that Prezi was presented to pupils in a Norway class and in the same way to the U.S class to find out whether there might be different responses to Prezi and PowerPoint depending on the cultural background from the user. Results showed that both software used by the students, then finally it is found that the new tool ran well in spite of the minimal direct instruction used by the teacher. Most made their presentations less linear rather than they would have made it in PowerPoint. They generally practiced the Prezi technique of grouping components and constructing a pathway between groups. Many students inserted multimedia such as links, photos, and videos. Some especially appreciated the Prezi features of more than one user is being able to work on a presentation in the same time. Peers enjoyed each other's presentations and found them fascinating. However, open-ended comments were more aimed at actual content than use of Prezi.

3. PowerPoint vs. Prezi: Finding the Right Device for the Job. White (2012: 37) as the writer who mentions on his research that the finding of using Prezi in presentation involves two main parts: (a) Understanding of information, $78 \%$ understood the message and there were no question, vice versa $22 \%$ understood a lot of the information and had question.; (b) Flow of information, 89\% idea of the information make sense and it was delivered smoothly, vice versa $11 \%$ thought the information was understood, but it did not flow smoothly

4. Using Prezi in the Classroom by Rogers, et.al. (2011) as the writers of this article have all applied Prezi as an instructional tool and they are offering advice to instructors who might be interested in 
mustering up the motivation to try Prezi. The authors states about the positive sides of Prezi used in the classroom. Prezi offers the capability for students to collaborate in class while using the program online. Up to 8 people can edit the Prezi in the same time. For those in bigger classes, this could be accomplished by splitting students into groups. This allows for the construction and presentation of students' knowledge that could appeal to different learning manners. Prezi is made more accessible for pupils and instructors through its free online style. Students can view the Prezi while and after class by practicing an online link.

5. Pedagogically sound use of Prezi: making beneficial use of Prezi in a class. The writer is Houska (2010) who mentions that he has received positive responses cane from his students as audience members regarding the use of Prezi in the classroom. He has not yet to have any students apply Prezi for a class presentation, but the writer is sure that he will create it in the years to come true. This type of presentation software permits to many new options relative to slide ware namely PowerPoint or Keynote.

6. Tech Tools for Teachers, By Teachers: Connecting Teachers and Students written by Manning, et al. (2011) who state that incorporating $21^{\text {st }}$ century technology to the classroom can be messy and problem at first, but with consistency, teachers are able to help students use these tools critically plus usefully to meet literacy goals. For instance, they can use Prezi to show information in a completely different format. By using innovative tools such as Prezi in order to approach learning, students and teachers can do it together to re-envision how school is going to function for the century to come.

\section{Research Gap}

In this writer's research, she could find some important points that were different from the related studies above. For instance, the first research is about a classroom action research for academic speaking students which used Prezi as the media, and the purpose is to find improvements in students' speaking skill.

After that, the second research is a research that Prezi was proposed to pupils in a Norway's class and in the U.S class at the same way to know whether there might be various responses to PowerPoint and Prezi. The third research is about a comparative research between Prezi and PowerPoint in general presentations. This research does not explain specifically about the use of Prezi and PowerPoint as the teaching media to teach a particular subject.

The fourth, it mainly discusses about pros, cons and suggestions to apply Prezi in the classroom. The fifth, the researchers talk about developing beneficial ways to practice this activity in the English/Language Arts in a class. The last study is about students' responses as audience members about using Prezi in the classroom. Meanwhile, in the writer' research is about an experimental research which 
REGISTER JOURNAL

Vol. 11, No. 2, Vol. 11, No. 2, 2018, pp.121-138 p-ISSN: 1979-8903 ; e-ISSN : 2503-O40X

Website: http://journalregister.iainsalatiga.ac.id/index.php/register/ http://dx.doi.org/10.18326/rgt.v11i2.154-167

compares Prezi and PowerPoint as the teaching media to teach speaking viewed from student's creativity. The purposes are to find which one is more superior and more useful to teach speaking. Thus, it can be said that this research is new and different from other studies.

\section{RESEARCH METHOD.}

\section{Techniques or Procedures of the research}

The technique used in this research was descriptive s plus inferential analysis. The descriptive one was used to know the mean, mode, median, and standard deviation of students score for each group. Inferential analysis was used to test the hypothesis. In this research, the writer also used ANOVA that requires normality test to know whether the data from population is distributed normally and homogeneity to know whether the groups that are compared are homogenous. To be clearer, it is designed as follows:

Table 1. Research Design

\begin{tabular}{lll}
\hline Creaching & $\begin{array}{l}\text { Prezi } \\
\left(\mathrm{A}_{1}\right)\end{array}$ & $\begin{array}{l}\text { PowerPoint } \\
\left(\mathrm{A}_{2}\right)\end{array}$ \\
\hline High & $\mathrm{A}_{1} \mathrm{~B}_{1}$ & $\mathrm{~A}_{2} \mathrm{~B}_{1}$ \\
Creativity $\left(\mathrm{B}_{1}\right)$ & & \\
Low & $\mathrm{A}_{1} \mathrm{~B}_{2}$ & $\mathrm{~A}_{2} \mathrm{~B}_{2}$ \\
Creativity $\left(\mathbf{B}_{2}\right)$ & & \\
\hline
\end{tabular}

Note:

$\begin{array}{ll}\text { Independent variable } & : \text { teaching media (Prezi and PowerPoint) } \\ \text { Experimental group } & : \text { the class taught by Prezi } \\ \text { Control group } & : \text { the class taught by PowerPoint } \\ \text { Dependent variable } & : \text { speaking skill } \\ \text { Moderator variable } & : \text { students' creativity }\end{array}$

In this study, test of speaking and creativity test became the instruments of collecting data. They were used to explore the experiences, measure the skill and knowledge. The blueprint of speaking skill as a design, which explains how speaking skill was achieved. It explains as follows: (1) the speaker can speak fluently; (2) the speaker produces extensive vocabularies; (3) the speaker uses very clear 
pronunciations (4) the speaker is able to make very few grammatical mistakes and (5) the speaker performs superior content of the task. Furthermore, the creativity test which was used to determine the low and high creativity is adapted from Munandar Creativity Test (Munandar: 1999).

\section{Validity and Reliability}

In order to get students' speaking skill data, the writer arranged some following steps: (1) students prepared a laptop with Prezi or PowerPoint software inside, (2) students chose one of the topics through lottery, (3) students collected the data and information to be presented based on the topic, (4) students designed the substantial of presentation linked to the topic by making Prezi or PowerPoint, (5) students presented the material by using Prezi or PowerPoint in front of the class, and (6) the students' speaking was recorded and scored by two scorers.

Before the research is carried out, the instrument of collecting the data must be well prepared and tried out to ensure that the instruction of the test of speaking is readable. This shows that the instructions of the two tests are readable since the percentages of the readability are more than $75 \%$. The instructions used in speaking test were as follows: (1) Present the material by using Prezi or PowerPoint in front of the class; (2) You have around 10-15 minutes to present the material. In detail, the first three minutes is for preparation, opening, self-introduction and delivering the topic's title, around ten minutes for maximum is to present the major topic, two minutes left is to draw conclusion and closing; (3) Do it as seriously as possible.

Normality and homogeneity test are done by using inferential analysis and they must be done before analyzing the data. The normality test functions to investigate whether the data is within normal distribution or not and the test of homogeneity is done to investigate whether the data are homogeneous. It shows that all of the samples $\left(\mathrm{L}_{\mathrm{o}}\right)$ are lower than $\left(\mathrm{L}_{\mathrm{t}}\right)$. Thus, the conclusion showed the data are in normal distribution. Then, It also shows that the $\chi_{0}^{2}(1.49)$ is fewer than $\chi_{t}^{2}(7.81)$. Thus, the conclusion showed the data are homogenous.

\section{RESULTS \& DISCUSSION}

Table 2. The Summary of ANOVA

\begin{tabular}{lllllll}
\hline $\begin{array}{l}\text { Source of } \\
\text { Variance }\end{array}$ & SS & df & $\mathbf{M S}$ & $\mathbf{F}_{\mathbf{o}}$ & $\mathbf{F}_{\mathbf{t}(0.5)}$ & Meaning \\
\hline $\begin{array}{l}\text { Between } \\
\text { Columns }\end{array}$ & 267.969 & 1 & 267.9688 & 4.831 & 4.08 & Significant \\
Between Rows & 1915.29 & 1 & 1915.29 & 34.529 & & Significant \\
\hline
\end{tabular}




\begin{tabular}{llllll}
\hline $\begin{array}{l}\text { Columns by } \\
\text { Rows }\end{array}$ & 0.11161 & 1 & 0.111607 & 0.002 & Not Significant \\
\end{tabular}

(Interaction)

Between Groups $\quad 2183.37 \quad 3 \quad 727.790$

Within Groups $\quad 2884.38 \quad 52 \quad 55.46875$

Total $\quad 5067.75 \quad 55$

According to the above figure, the summaries are:

a) Since $F_{o}$ between columns (4.831) is bigger than $F_{t}$ at the level of significance $\alpha=0.05(4.08), H_{o}$ is rejected and the distinction between columns is significant. Since the mean of $A_{1}$ (74.55) is bigger than that of $\mathrm{A}_{2}$ (70.18), so the conclusion showed Prezi is more useful than PowerPoint to teach speaking.

b) Since $F_{o}$ between rows (34.529) is bigger than $F_{t}$ at the level of significance $\alpha=0.05(4.08), H_{o}$ is rejected and the distinction between rows is significant. The conclusion is the speaking ability of high creative students and low creative students are undoubtedly distinctive. Furthermore, since the mean between $B_{1}$ (78.21) is bigger than $B_{2}(66.51)$, the inference is the high creative students are more superior than low creative students in speaking ability.

This research is one of the efforts to generate some improvement to teach speaking for professional context toward university students. It has been discussed in the previous chapter that Prezi is one of the alternatives to obtain the intention. These are the elaboration discussions of the study results.

1. Prezi is more useful than PowerPoint.

Based on data description of students' score in experimental class $\left(\mathrm{A}_{1} / \mathrm{Prezi}\right)$, it shows that the mean is 74.75. Meanwhile, in the data description of students' score in control class ( $\mathrm{A}_{2} /$ PowerPoint), it shows that the mean is 70.35 . Thus, the fact shows the mean of students' score taught by Prezi (74.75) is bigger than the mean of students' score taught by PowerPoint (70.35), so the inference means Prezi is more useful than PowerPoint to teach speaking.

Prezi implementation in teaching speaking helps students practice speaking usefully. Prezi is suitable in teaching speaking because the goal of teaching Speaking in Professional Context is to make students able to make, use, or apply the material of Speaking in Professional Contexts creatively. Students are encouraged to make the speaking material by using Prezi. It is considered that Prezi is more attractive than PowerPoint if it is used to present the material, so the audiences are more interested in paying attention to the presentation. It is in line with Sari (2014: 932) who states 
that Prezi owns more superior visual creation which can attract audiences to stay and enjoy the performance and through practicing Prezi, the users can elaborate the features to perform their ideas.

Furthermore, the plus point of Prezi is the zooming feature which presents an idea of a big picture as a framework for the audiences. It can be zoomed in and zoomed out amazingly. Students can use this zooming feature to emphasize and explain clearly small parts of their presentations. Using Prezi as an useful presentation tool is also supported by White (2012: p. 37) who mentions that the effect of applying Prezi in presentation includes two major things: (1) Flow of information: 89\% idea of the information understood and flowed well, and (2) Understanding of information, 78\% understood the message and had no question.

Then, the Prezi map and the templates allow students to organize the content of the presentation material. They can do it by grouping the similar topic and connecting some topics in order to be easily understood. Thus, those activities avoid students add irrelevant content. Fortunately, those activities can also be seen only in one screen capture. Naturally, the zooming feature, Prezi map, templates, and other unique Prezi features do not exist in PowerPoint. These findings are supported by Manning, et al. (2011: 4). They say that Prezi allows students to have choices of making more scopes, to examine an issue, and to combine their thinking and ideas into a direct site.

In addition, if students want to make a truly distinguish Prezi, they would rather start blank Prezi and use their creativity to gather and connect the topic into well-organized presentation.The purpose is to make the students deliver their idea and material in the well oral presentation. They also can use the zooming feature of Prezi to emphasize their explanation and convince the audience during speaking. It is related to what White (2012: 1) states that Prezi is a device that allows the students to insert concepts, pictures, and video onto a big empty canvas then zoom in and out on particular things so that it can stress the significance.

Many students who were taught used Prezi were able to improve their speaking skill. It could be examined during the treatment where some pupils performed presentations and their friends examined them personally by using an assessment sheet. This was applied to measure the speaking indicators from the presenters. The indicators of speaking involving vocabulary, fluency, pronunciation, content, and grammar were developed through an activity where pupils were asked to make a presentation related to a topic. In performing a presentation, pupils produced extensive and appropriate vocabularies, they could speak fluently in using expressions according to the topic, they used very clear and appropriate 
REGISTER JOURNAL

Vol. 11, No. 2, Vol. 11, No. 2, 2018, pp.121-138 p-ISSN: 1979-8903 ; e-ISSN : 2503-040X

Website: http://journalregister.iainsalatiga.ac.id/index.php/register/ http://dx.doi.org/10.18326/rgt.v11i2.154-167

pronunciations, and they performed relevant ideas in performing their works about the topic, and they were able to use proper grammars,.

In addition, based on students' interview, the author also found that the implementation of Prezi features in designing texts namely limited color and font options were naturally made students' presentations looked simple plus easy to be understood. Afterward, the zooming features of Prezi also made students an ease to move directly to a specific explanation. For example, once they had to present about their ending session by showing a quote, students were able to move or go directly into the specific destination, then closing the presentations by coming back with the big picture of their concepts.

On the contrary, PowerPoint is a standard-based presentation tool. This teaching media makes students less cheerful in teaching learning process because they admit that it is just ordinary presentation tool. Additionally in performance time, students have difficulty to zoom out a specific part of the topic. It is true because PowerPoint does not have zooming feature such as White's opininion that (2012: 16) in PowerPoint the students have problems in grabbing to a particular place one while the presentation was running, and it cannot zoom the small part. Then, the large size of letter and color options in PowerPoint makes students overuse it. It becomes unclear and it influences their fluency in speaking. In a survey taken in 2003, the effects highlighted on special features of a PowerPoint presentation that users felt troublesome, such as; ... the text cannot be seen, it is too small, ... and the color options on the slide cannot be seen too. (Paradi, 2003 in White, 2012: 11).

According to the explanations, it can be summed that Prezi is more useful than PowerPoint to teach speaking, because Prezi has the concept that present information in concise ways that underline the organization of the idea which influences students' speaking aspects in their presentations.

2. The Students Having High Creativity Have More superior Speaking Skill Than Those Having Low Creativity

Based on the data description of pupils' score in speaking test, the mean between students having high creativity $\left(B_{1}\right.$ is 78.29$)$ is bigger than students having low creativity ( $B_{2}$ is 67.36$)$, it can be concluded that the high creative students are more superior than low creative students in speaking ability.

Theoretically, the high creative students are more superior influence in teaching and learning speaking skill. The students will be more active in participating in the class, because those who have high verbal creativity will be easier in analyzing visual information, designing new format and 
presenting their creation in a skillful way. It is strengthened by Benlamri's statement (2013:8) that creativity is a natural part of everyone's mental process, any act of producing something new, even something as simple as a sentence that has never been spoken before, is an act of creation.

In contrast, inferior creative students inclined to be inactive when they are asked to speak up in the speaking class. They are ashamed to perform because they are affraid of doing errors. They do not like an openness to learn and try new things, they carry out something ordinaryly, and they do not try to expand their thought well. They also have less effort to achieve a more superior product of creativity especially in speaking class. They have a monotonous concept, idea, creation in solving the problem. The matters stated in the previous are since the pupils do not concentrate on their works, Guest (1987, in Paauwe 2004: 55) mentions that low creative students trivialize their value, consider less of themselves, and concentrate on their drawbacks. Furthermore, McGhee in Safertzi, 2000: p. 21 defines that many people consider less creatively when they are not solemnly and intenty concentrate on the duty. Thus, the inference is high creative students are more superior than low creative students in performing speaking ability.

\section{CONCLUSION}

It has been clearly described on the previous chapter that the research findings are as follows: (1) Prezi is more useful than PowerPoint in teaching speaking for professional context; and (2) The high creative students are more superior than low creative students in speaking skill.

According to the research finding, the conclusion is that Prezi is more useful than PowerPoint to teach speaking. Prezi is suitable in teaching speaking because the goal of teaching Speaking in Professional Context is to make students able to make, use, or apply the material of Speaking in Professional Contexts creatively. Students are encouraged to make the speaking material by using Prezi. They have to create Prezi presentation to show their works by presenting them in front of the class. In Prezi activity, students have to make a presentation with their groups based on the topic. Prezi is also appropriate for high and low creative students since it has flexible movement which helps students can organize the topic into the meaningful sentences. In the relation to speaking skill for planning process, the function of Prezi is to help the presenter to generate ideas easily, because it provides the concept of information related to the topic that is presented.

Thus, the writer suggests that: (1) for the teachers, they should use Prezi to teach speaking to improve students' speaking skill but the teachers have to be able to prepare Prezi properly and understand the potency and drawback of Prezi so that they can implement this teaching media usefully in the teaching and learning process in the classroom; (2) for the students, they are expected to be more active in the class so that it can improve their speaking ability. Then, it is suggested for the students who have low skill in 
REGISTER JOURNAL

Vol. 11, No. 2, Vol. 11, No. 2, 2018, pp.121-138 p-ISSN: 1979-8903 ; e-ISSN : 2503-O40X

Website: http://journalregister.iainsalatiga.ac.id/index.php/register/ http://dx.doi.org/10.18326/rgt.v11i2.154-167

speaking to involve more in joining the activity in class; (3) for further researchers, they can apply the finding of this study as the beginning for conducting the next investigation and they can also develop the teaching media used in this research as a way of making revision to the weaknesses of this research.

\section{REFERENCES}

Alajaili, Hetham M. A. (2014). The Usefulness of Graphic Organizers to Teach Speaking Viewed from Students' Creativity (Tesis). Surakarta: Universitas Sebelas Maret.

Ansori, M. Iksan. (2012). Efektivitas Pembelajaran yang menggunakan Hypermedia dan Slide PowerPoint terhadap Prestasi Belajar Mata Pelajaran Pendidikan Agama Islam ditinjau dari Kemampuan Visuospasial di SMA Negeri se-Kabupaten Nganjuk Tahun Ajaran 2012/2013 (Tesis). Surakarta: Universitas Sebelas Maret.

Barber, Cam. (2013). Prezi Versus PowerPoint for Presentation Visual. Retrieved from http://vividmethod.com/prezi-versus-powerpoint-for-presentation-visuals/

Benlamri, Fatima. (2013). Creative Teaching to Increase Students' Achievements in Speaking (A Dissertation). Retrieved from http://dspace.univbiskra.dz:8080/jspui/bitstream/123456789/4805/1/cover\%20page_R\%C3\%A9sum\%C3\%A9.pd $\underline{f}$

Brock, Sabra and Brodahl, Cornelia. (2013). A Tale of Two Cultures: Cross Cultural Comparison in Learning the Prezi Presentation Software Tool in the US and Norway. Journal of Information Technology Education: Research, Volume 12.

Brown, Douglas H. (2003). Language Assessment: Principles and Classroom Practices. -: Longman

Harris, Michael and Paul McCann. (1994). Assessment. -: Macmillan Oxford

Houska, Jeremy Ashton. (2010). Pedagogically sound use of Prezi: making useful use of Prezi in the classroom. Retrieved from ttp://www.apa.org/ed/precollege/ptn/2013/05/prezisound.aspx

Hughes, Arthur. (2003). Testing for Language Teachers (Second Edition). New York: Cambrige University Press.

Magno C. \& Ouano J. (n.d). Designing Written Assessment of Student Learning.

Manning, et al. (2011). Tech Tools for Teachers, By Teachers: Bridging Teachers and Students. The Wisconsin Council of Teachers of English, 53, 1-27. 
Munandar, Utami. (1999). Pengembangan Kreativitas Anak Berbakat. Jakarta: Depdiknas dan Rineka Cipta.

Paauwe, J. (2004). HRM and Performance: Achieving Long-termViability. Oxford: Oxford University Press.

Pujasari, Ratu Sarah. (2014). The Usefulness of Community Language Learning in Teaching Speaking Viewed from Students' Creativity (Thesis). Surakarta: Universitas Sebelas Maret. In text: Pujasari (2014)

Rogers, E.M., Settle, Q., Abrams, K. M., Baker, L. M. (2011). Teaching Tips/Notes: Using Prezi in the Classroom. North American Colleges and Teachers of Agriculture (NACTA) Journal. December 2011, 105-106.

Safertzi, Eleni. 2000. Creativity. INNERGIO: dissemination of innovation and knowledge management technique.

Sari, Dwi Rosita. (2014). Prezi: An Online to Offline 'Zooming' Presentation Software in Oral English for Academic Speaking Students. The 61 TEFLIN International Conference (Proceeding 3). Surakarta: UNS Solo. In text: Sari (2014)

Sharif, Brwa Rasul. (2012, November 12). Teaching Speaking [PowerPoint slides]. Retrieved from http://www.slideshare.net/brwarsharif/teaching-speaking-15225983

Sujiyana. (2010). Implementing Group Presentation Using PowerPoint (GPPPt) to Improve the Students' Speaking Competence (Thesis). Surakarta: Universitas Sebelas Maret.

Tadris Bahasa Inggris (TBI). (2011). Silabi Mata Kuliah Program Studi TBI (Tadris Bahasa Inggris). Salatiga: Institut Agama Islam Negeri. In text: TBI (2011)

White, Nicole. (2012). Prezi v. PowerPoint: Finding the right tool for the job. New York: State University of New York Institute of Technology 